\title{
Mass production of the entomopathogenic nematode, Steinernema carpocapsae on Tenebrio molitor and Spodoptera litura
}

\author{
HERI PRABOWO ${ }^{1, \boldsymbol{v}}$, SRI ADIKADARSIH ${ }^{1}$, JANIS DAMAIYANI ${ }^{2}$ \\ ${ }^{1}$ Indonesian Sweetener and Fiber Crops Research Institute. Karangploso, Malang East Java, Indonesia. Tel.: +62-341-491447, Fax.: +62-341-485121, \\ `email: heri_prabowo@mail.litbang.pertanian.go.id, heribalittas@gmail.com \\ ${ }^{2}$ Purwodadi Botanic Gardens, Indonesian Institute of Sciences. Jl. Surabaya-Malang Km 65, Pasuruan 67163, East Java, Indonesia
}

Manuscript received: 20 November 2018. Revision accepted: 25 April 2019.

\begin{abstract}
Authors. 2019. Mass production of the entomopathogenic nematode, Steinernema carpocapsae on Tenebrio Molitor and Spodoptera litura. Biodiversitas 20: 1344-1349. Steinernema carpocapsae is the most developed biological agents to control pests nowadays, to support this nematode as a biological agent mass production technique is required. $S$. carpocapsae can be produced via in vivo methods. In vivo production has some advantages, such as cheap, easy, and sustainable to be developed in small farm agriculture. The purpose of this research was to evaluate the mass production of S. carpocapsae using Tenebrio molitor and Spodoptera litura larvae as hosts. Twenty-five last instar larvae were inoculated with different concentrations of infective juvenile (IJ) (e.g., 100, 200, 300 and $400 \mathrm{IJ} /$ larvae) of $S$. carpocapsae Asembagus. The production of $S$. carpocapsae with concentrations of 100, 200,300 and $400 \mathrm{IJ} / \mathrm{larvae}$ on $T$. molitor and $S$. litura showed $3.62 \times 10^{3} ; 6.29 \times 10^{3} ; 1.13 \times 10^{4} ; 1.52 \times 10^{4} ; 1.13 \times 10^{4} ; 1.46 \times 10^{4} ; 1.54 \times 10^{4}$; and $1.94 \times 10^{4} \mathrm{IJ} / \mathrm{larvae}$, respectively. The IJ harvest from $T$. molitor and $S$. litura shows the longest body length for IJ at a concentration of $400 \mathrm{IJ} /$ larva of $437.48 \mu \mathrm{m}$ and $591.42 \mu \mathrm{m}$, respectively. This study indicates that $T$. molitor and $S$. litura can be used to produce $S$. carpocapsae. The production of $S$. carpocapsae with a concentration of $400 \mathrm{IJ} /$ larvae on T. molitor and S. litura showed the highest total yield and body length of IJ.
\end{abstract}

Keywords: In vivo, mass production, Spodoptera litura, Steinernema carpocapsae, Tenebrio molitor

\section{INTRODUCTION}

The utilization of chemical insecticides could trigger an explosive growth of the pest population. Such explosion of the pest population is possible when a pest becomes resistant to insecticides so that its population turns out of control. The higher a pest's level of tolerant of insecticides, the more the insecticide dosage is required (NicolopoulouStamati et al. 2016; Parween et al. 2014). Moreover, chemical insecticides also bring other disadvantages, such as killing the predator and parasitoid, human poisoning, and environmental contamination (Kumar 2012; Horowitz and Ishaaya 2012). Those negative effects caused by chemical insecticides create an opportunity to develop an eco-friendly pest control as an alternative. One of the alternatives of eco-friendly pest controls is biological pest control, which focuses on the utilization of insect pathogen such as bacteria, fungi, viruses, and nematodes (Lazarovits et al. 2007; Kaya and Vega 2012; Lacey and Georgis 2012). One of the insect pathogens that are used as biological pest controller is entomopathogenic nematodes (EPNs) Steinernema sp. (Koppenhöfer et al. 2012; Dillman et al. 2012). Seven nematode families are utilized as biological pest agents including Mermithidae, Allantonematidae, Tetradomatidae, Phaenopsitylenchydae, Sphaerulariidae, Steinernematidae, and Heterorhabditidae (Lacey et al. 2001; Lewis and Clarke 2012; Van Zyl and Malan 2014; Půža 2015). However, nematode families of Steinernematidae and Heterorhabditidae are the most developed biological agents to control pests nowadays (Glazer and Lewis 2000). S. carpocapsae that is categorized under the Steinernematidae family is proven to be potential to infect more than 250 species of insects from 75 families and 11 orders (Poinar 1990). Besides, there are more than 25 Steinernema strains isolated from various countries, and even it has been commercially produced in various formulations in some countries such as Austria, Germany, Japan, England, Columbia, Canada, and Australia (Grewal and Georgis 1999).

Steinernema is categorized under Steinernematidae family that can associate with bacteria Xenorhabdus sp. in eliminating the targeted pests (Boemare and Tailliez 2009; Stock and Hunt 2005). The Steinernema stadium that can cause high mortality of the targeted larvae is juvenile infective (IJ) stage. IJ enters the larvae through integument, spiracle, anus, and mouth. It is possible for IJ to penetrate the insect hosts when it is drawn by $\mathrm{CO}_{2}$ produced by the targeted insect hosts (Batalla-Carrera et al. 2014). In case of penetrations through mouth or anus, IJ will go through the abdominal wall to reach hemocoel, while in case of penetration through spiracle, the juvenile will pass through the trachea wall to reach the hemocoel. The juvenile will release its symbiotic bacteria. The symbiotic bacteria shall form a supporting environment for nematode development by producing antibiotics that prevent the growth of other competitive microorganisms and turn the insect host cells as food sources for nematodes so that the insect host will be killed by septicemia (Constant et al. 2010; Poinar and Grewal 2012). The IJ is a phase where the larvae live 
outside the pest hosts in which the IJ was created, the larvae are weather tolerant, and the larvae are able to infect new pest hosts (Lewis et al. 2006).

As a matter of fact, when compared with chemical insecticides, the use of nematode generally requires a higher price (Arthurs et al. 2004). Besides, nematodes have a shorter life span, low stability, and require specific knowledge to be applied, which include knowledge of the nematode maintenance until nematode storage (Umamaheswari et al. 2006). Such fact limits the utilization of nematodes as a biocontrol agent to farmers who are already equipped with the necessary skills and knowledge to use it (Shapiro-Ilan et al. 2002; Ehlers 2007). Nevertheless, in relation to a regulation and prohibition given through the Food Quality Protection Act of 1996 that stipulates the chemical insecticide usage limitation to prevent it from poisoning humans and contaminating the surrounding environment (Anonymous 1996) and in connection with the movement of eliminating chemical insecticide usage, it is considered as necessary to use a save biological pest controller especially through the utilization of pathogen Steinernema sp. (Koppenhöfer and Fuzy 2009). In addition to its eco-friendly characteristic, the use of nematode Steinernema sp. as a biological pest controlling agent offers more advantages, such as ecofriendly, high possibility of mass production (Georgis et al. 2006; Koppenhöfer and Kaya 2002; Bjorson and Schutte 2003), and highly tolerant of various kinds of chemical insecticides when applied together (Pino and Jove 2005; Elawad et al. 2007). In addition, nematodes actively seek for the targeted pest hosts Campbell and Lewis 2002), do not harm vertebrates (Ehlers 2003), and can be applied with a standard applicator, which is generally used for chemical pesticides (Wright et al. 2005).

A nematode mass production technique is required to support the usage of $S$. carpocapsae as a biological agent. The production of $S$. carpocapsae can be both in vitro and in vivo. The in vitro production is done by an artificial diet, while the in vivo production is done through insect hosts. In vitro production depends on specialized knowledge, modern technology availability, and complex materials (McMullen and Stock 2014).

In vivo production offers some benefits, which include the requirement of simple production tools and technologies, easy to be applied, and it produces higher quality nematodes (Grewal dan Georgis 1999). The in vivo production of $S$. carpocapsae solely depends on the availability of inexpensive pest hosts that could massively produce quality $S$. carpocapsae (Hazir et al. 2001).

Spodoptera litura (Lepidoptera: Noctuidae) and Tenebrio molitor L. (Coleoptera: Phylaridae) can be used as alternative pest hosts for some benefits, such as they can be used to produce various kinds of strain Steinernema spp., require easy maintenance and low maintenance cost, and able to massively produce IJ (Hazir et al. 2003; Gaugler and Han 2002). The in vivo production of $S$. carpocapsae relies on the fitness between the strain $S$. carpocapsae and the pest host. Only particular strains of $S$. carpocapsae can be produced in one kind of pest host for several types of nematodes have typical characteristics. $S$. carpocapsae offers many benefits.

This study focused on mass production of $S$. carpocapsae Asembagus on T. molitor and S. litura larvae. It is paramount to obtain information on its production ability in $T$. molitor and $S$. litura in the necessary number and length of IJ and with an effective concentration for the production of $S$. carpocapsae isolates.

\section{MATERIALS AND METHODS}

\section{Mass rearing of insect hosts}

Larvae of $S$. litura were collected from Karangploso Experimental Station, Malang, East Java. The larvae were allowed to feed on leaves of Chinese cabbage (Brassica rapa var. chinensis) in a plastic jar $(1.5 \mathrm{~kg})$ that was covered with gauze for ventilation under laboratory condition. They were kept until developed into pupae. The pupae were collected and placed inside of another plastic jar up to adult emergence. Male and female moths were allowed to mating and produce egg masses. The egg masses were kept for hatching. The newly hatching larvae were collected and reared on cabbage leaves to produce 6th instar. The last instar of F2 generation was used for mass production of the nematodes (Prabowo et al. 2016).

Larvae of $T$. molitor were collected from Ngenep Market, Malang, East Java. The larvae were allowed to feed on carrot in a plastic jar $(1.5 \mathrm{~kg})$ that was covered with gauze for ventilation under laboratory condition. They were kept until developed into pupae. The pupae were collected and placed inside of another plastic jar up to adult emergence. Male and female weevils were allowed to mating and produce egg masses. The egg masses were kept for hatching. The newly hatching larvae were collected and reared on carrot to produce last instar of $T$. molitor. The last instar of F2 generation was used for mass production of the nematodes.

\section{Nematodes}

The isolates used in this study was $S$. carpocapsae isolated as Asembagus, East Java, Indonesia, and this isolates were the collection of Indonesian Sweetener and Fiber Crops Research Institute. IJ identification based on morphology and body length based nematode identification by Adam and Nguyen (2002). Stage III juvenile infective (IJ) was used in this research. Nematodes were reproduced in vivo in T. molitor. IJ was recovered using white traps method and after being harvested the IJ was then stored in a refrigerator $\left(5-15^{\circ} \mathrm{C}\right)$. All the IJs used in this study were harvested two weeks prior to the study to maintain its viability. The nematodes were acclimated in room temperature for one day prior to its use.

\section{Mass production of nematodes}

The IJ concentrations used in the study are categorized into $100 \mathrm{IJ} /$ larva, $200 \mathrm{IJ} /$ larva, $300 \mathrm{IJ} /$ larva, and 400 IJ/larva with 25 larvae involved in each repetition. Stage three juvenile infective (IJ) was used for production. The inoculation of IJ to insect larvae by using a filter paper 
method. First, the filter paper was cut by the surface area of a $10 \mathrm{~cm}$ diameter Petri dish. Next, the filter paper was then put under the Petri dish. Finally, the Petri dish was incubated at room temperature. The observed parameters were total IJ production since the first until last harvest, the total harvest of IJ, length of IJ harvested since the first until last harvest, and the average length of IJ.

\section{Statistical analysis}

The observed parameters were then analyzed via variance analysis with SPSS package. When a significant F-value $(p<0.05)$ was found, differences between observed parameter were compared using The Duncan's Multiple Range Test (DMRT) 5\% mean separation test.

\section{RESULTS AND DISCUSSION}

\section{Harvested S. carpocapsae nematodes on $T$. molitor and S. litura}

The IJ production in T. molitor and $S$. litura hosts show harvested IJ between $1.93 \times 10^{3}-3.55 \times 10^{4} \mathrm{IJ} /$ larva. Both $T$. molitor and $S$. litura showed the highest production rate on the $4^{\text {th }}$ and $6^{\text {th }}$ day of $1.60 \times 10^{3}$ and $3.22 \times 10^{4} \mathrm{IJ} /$ larva. After the highest production rate has been reached, the production continuously reduced up to the $20^{\text {th }}$ day. The lowest production in both host larvae was found on the $20^{\text {th }}$ harvesting day of $0.13 \times 10^{2} \mathrm{IJ} /$ larva. Such $20^{\text {th }}$-production was not suitable to be harvested since it would cost a higher IJ production cost in both hosts. Low productions of IJ in its early harvesting times may be attributed to the early stage of the first generation IJ that was newly penetrated into the host, which was not yet developed. As can be seen on the next harvests, there was increasing production of IJ because the IJs had multiplied inside the hosts. There was a decrease on the harvested IJ after the fifth harvest since the nematodes had consumed all the nutrition inside the hosts in 2-8 days since it was penetrated into the hosts. Therefore, the nutrition had been reduced drastically after the $5^{\text {th }}$ day, correlating the reduced production rate of nematodes. The reproduction rate and harvesting ability of nematodes are greatly affected by the type of the host and nematodes. The results of this research proved that the nematodes harvest rate decreases after the fifth day of penetration and that it is a feasible trend. According to Zaki et al. (2000), the highest S. carpocapsae harvest from Bombyx mori larvae of $3.1 \times 10^{4}$ could be seen on the twentieth harvesting day. As reported by Mahar et al. (2004), the productions of IJ S. carpocapsae, S. abbasi, $S$. karii, and S. riobravis on the 45th day were $1.6 \times 10^{4}$, $5.9 \times 10^{2}, 4.2 \times 10^{2}$, and $4.4 \times 10^{2}$, respectively whereas there was $10^{4} \mathrm{IJ}$ Heterorhabditis marelatus production. ShapiroIlan et al. (2008) stated that nematodes heavily depend on the nutrition contained in the insect hosts for their fitness, reproduction capability, and success in infecting the hosts. Hence, the harvest on the $20^{\text {th }}$ day since the IJ investment did not show any nematodes because there was not any nutrition left so that IJ was unable to reproduce. The harvest tests conducted in every two days up to the twentieth day showed that the IJ on T. molitor and S. litura reached a maximum number on the tenth day, afterward the tenth day and the IJ would decrease afterward (as shown in Table 1 and 2).

Table 1. Harvested S. carpocapsae IJ inoculated with concentration with different concentrations using Tenebrio molitor as host

\begin{tabular}{|c|c|c|c|c|c|c|c|c|c|c|}
\hline \multirow{2}{*}{$\begin{array}{l}\text { Concentra- } \\
\text { tion of IJ } \\
\text { (JI/larvae) }\end{array}$} & \multicolumn{10}{|c|}{$\begin{array}{c}\text { Harvested IJ (IJ/larvae) } \\
\text { Days of IJ harvested }\end{array}$} \\
\hline & 2 & 4 & 6 & 8 & 10 & 12 & 14 & 16 & 18 & 20 \\
\hline 100 & $1,93 \times 10^{3} \mathrm{a}$ & $7,83 \times 10^{2} \mathrm{a}$ & $4,73 \times 10^{2}, \mathrm{a}$ & $0,97 \times 10^{2} \mathrm{a}$ & $1,07 \times 10^{2} \mathrm{a}$ & $1,07 \times 10^{2} \mathrm{a}$ & $0,73 \times 10^{2} \mathrm{a}$ & $0,33 \times 10^{2} \mathrm{a}$ & $0,23 \times 10^{2} \mathrm{a}$ & $0 \mathrm{a}$ \\
\hline 200 & $2,06 \times 10^{3} \mathrm{a}$ & $1,21 \times 10^{3} \mathrm{ab}$ & $7,33 \times 10^{2} \mathrm{a}$ & $1,26 \times 10^{2} \mathrm{a}$ & $1,87 \times 10^{2} \mathrm{a}$ & $1,36 \times 10^{2} \mathrm{a}$ & $1,17 \times 10^{2} \mathrm{a}$ & $1,20 \times 10^{2} \mathrm{a}$ & $0,27 \times 10^{2} \mathrm{a}$ & $0 \mathrm{a}$ \\
\hline 300 & $2,39 \times 10^{3} \mathrm{ab}$ & $1,60 \times 10^{3} \mathrm{~b}$ & $7,47 \times 10^{2} \mathrm{a}$ & $1,27 \times 10^{2} \mathrm{a}$ & $2,23 \times 10^{2} a$ & $6,10 \times 10^{2} \mathrm{a}$ & $3,37 \times 10^{2} \mathrm{a}$ & $1,93 \times 10^{2} \mathrm{a}$ & $0,53 \times 10^{2} \mathrm{a}$ & $0,13 \times 10^{2} \mathrm{a}$ \\
\hline 400 & $3,35 \times 10^{3} \mathrm{~b}$ & $1,60 \times 10^{3} \mathrm{~b}$ & $9,83 \times 10^{2} \mathrm{~b}$ & $3,17 \times 10^{2} \mathrm{~b}$ & $2,27 \times 10^{2} a$ & $7,73 \times 10^{2} b$ & $6,20 \times 10^{2} b$ & $5,56 \times 10^{2} \mathrm{~b}$ & $0,63 \times 10^{2} \mathrm{a}$ & $0,15 \times 10^{2} a$ \\
\hline
\end{tabular}

Note: values followed by the same letter in the same column are not significantly different according to DMRT with a $95 \%$ confidence level

Table 2. Harvested S. carpocapsae IJ with a concentration of 100, 200, 300, and 400 IJ/larvae on S. litura.

\begin{tabular}{|c|c|c|c|c|c|c|c|c|c|c|}
\hline \multirow{2}{*}{$\begin{array}{c}\text { Concentration of IJ } \\
\text { (JI/larvae) }\end{array}$} & \multicolumn{10}{|c|}{$\begin{array}{l}\text { Harvested IJ (IJ/larvae) } \\
\text { Days of IJ harvested }\end{array}$} \\
\hline & 2 & 4 & 6 & 8 & 10 & 12 & 14 & 16 & 18 & 20 \\
\hline 100 & $1,28 \times 10^{4} \mathrm{a}$ & $1,64 \times 10^{4} \mathrm{a}$ & $1,85 \times 10^{4} \mathrm{a}$ & $1,89 \times 10^{4} \mathrm{a}$ & $2,28 \times 10^{4} \mathrm{a}$ & $1,16 \times 10^{4} \mathrm{a}$ & $4,80 \times 10^{3} \mathrm{a}$ & $4,40 \times 10^{3} \mathrm{a}$ & $1 \times 10^{3} \mathrm{a}$ & $0 \mathrm{a}$ \\
\hline 200 & $1,60 \times 10^{4} \mathrm{a}$ & $3,65 \times 10^{4} \mathrm{ab}$ & $2,05 \times 10^{4} \mathrm{a}$ & $2,24 \times 10^{4} \mathrm{a}$ & $2,00 \times 10^{4} \mathrm{a}$ & $1,23 \times 10^{4} \mathrm{a}$ & $7,47 \times 10^{4} \mathrm{a}$ & $7,47 \times 10^{3} \mathrm{a}$ & $3,20 \times 10^{3} \mathrm{a}$ & $0 \mathrm{a}$ \\
\hline 300 & $2,93 \times 10^{4} \mathrm{ab}$ & $2,51 \times 10^{4} \mathrm{~b}$ & $3,09 \times 10^{4} \mathrm{a}$ & $1,87 \times 10^{4} \mathrm{a}$ & $1,76 \times 10^{4} \mathrm{a}$ & $1,17 \times 10^{4} \mathrm{a}$ & $9,07 \times 10^{4} \mathrm{a}$ & $6,40 \times 10^{3} \mathrm{a}$ & $3,47 \times 10^{3} \mathrm{a}$ & $0 \mathrm{a}$ \\
\hline 400 & $2,99 \times 10^{4} \mathrm{~b}$ & $2,67 \times 10^{4} \mathrm{~b}$ & $3,22 \times 10^{4} \mathrm{~b}$ & $1,99 \times 10^{4} \mathrm{~b}$ & $1,88 \times 10^{4} \mathrm{~b}$ & $1,22 \times 10^{4} \mathrm{~b}$ & $1,01 \times 10^{4} \mathrm{~b}$ & $9,50 \times 10^{3} \mathrm{a}$ & $3,55 \times 10^{3} \mathrm{a}$ & $0 \mathrm{a}$ \\
\hline
\end{tabular}

Note: values followed by the same letter in the same column are not significantly different according to DMRT with a $95 \%$ confidence level 
Table 3. Total of harvested $S$. carpocapsae IJ with a concentration of 100, 200, 300, and $400 \mathrm{IJ} /$ larvae on T. molitor and S. litura

\begin{tabular}{ccc}
\hline $\begin{array}{c}\text { Concentration of IJ } \\
\text { (JI/larvae) }\end{array}$ & \multicolumn{2}{c}{$\begin{array}{c}\text { Total of IJ harvested } \\
\text { (IJ/larvae) }\end{array}$} \\
\hline 100 & \multicolumn{1}{c}{ T.molitor } & S.litura \\
200 & $3,62 \times 10^{3} \mathrm{a}$ & $1,13 \times 10^{4} \mathrm{a}$ \\
300 & $4,72 \times 10^{3} \mathrm{a}$ & $1,46 \times 10^{4} \mathrm{~b}$ \\
400 & $6,29 \times 10^{3} \mathrm{a}$ & $1,52 \times 10^{4} \mathrm{c}$ \\
\hline
\end{tabular}

Note: values followed by the same letter in the same column are not significantly different according to DMRT with a $95 \%$ confidence level

The highest production of IJ on T. molitor and S. litura was found in $400 \mathrm{IJ} /$ larva concentrations producing 8.51 $\mathrm{x} 10^{3}$ and $1.94 \times 10^{4} \mathrm{IJ} /$ larva respectively. The production of IJ shows a positive correlation with the initial IJ concentrations. The $400 \mathrm{IJ} /$ larva concentrations produced the highest IJ followed by the $300 \mathrm{IJ} /$ larva, $200 \mathrm{IJ} /$ larva, and $100 \mathrm{IJ} /$ larva concentrations (as demonstrated in Table 3 ). It is possible since the more IJ that is given, the higher the possibility it would penetrate into the insect hosts. The invested IJ will reproduce 2-3 generations and with a high reproduction rate of IJ leads to a higher possibility for its next generations to multiple. Thus, a high IJ reproduction is more likely to be found in an insect host with a high IJ concentration than the one with a low IJ concentration. A high IJ concentration goes together with a high harvest.

The use of alternative hosts has been frequently practiced in producing $S$. carpocapsae. Alternative hosts such as Spodoptera litura, Plutella xylostella, Crocidolomia binotalis, Galleria mellonella, and Heliothis virescens (Miles et al. 2000), are proven to be reliable for production. Nonetheless, $G$. mellonella is the most frequently suggested host for its compatibility with various types of nematodes and its ability to produce a large harvest (Shapiro-Ilan et al. 2002). However, G. melonella is quite rare in Asia especially Indonesia. Therefore, the development of alternative hosts besides $G$. melonella that can make a high production rate is essential. S. abbasi and $S$. riobrave production on $G$. mellonella produces $2.2 \times 10^{5}$ IJ/larvae (Elawad et al. 1999). The $S$. carpocapsae isolates inoculation number 30,43 , and 45 on $T$. molitor produces $8.3 \times 10^{5}-1.2 \times 10^{6} ; 9.6 \times 10^{5}-1.3 \times 10^{6}$; and $1.2 \times 10^{6}-1.9 \times 10^{6}$ IJ/ gram biomass, respectively. On the other hand, $S$. carpocapsae isolates number 30,43 , and 45 that are inoculated on $T$. rufivena respectively produce $9.3 \times 10^{5}$ $1.4 \times 10^{6} ; 1.1 \times 10^{6}-1.3 \times 10^{6}$; and $1.3 \times 10^{6}-2.1 \times 10^{6} \mathrm{IJ} / \mathrm{gram}$ biomass (Prabowo 2007). When measured up to IJ production on G. mellonella, T. molitor, and Tirathaba rufivena, the production of $S$. carpocapsae Asembagus isolates IJ on $T$. molitor and $S$. litura has a potency to be higher although the harvest is still lower than other hosts.

\section{Length of $S$. carpocapsae nematodes harvested the different hosts}

The quantity and quality of the harvested nematodes present the quality of the hosts in producing insect pathogens. The quality of the harvested nematodes can be observed based on the quantity of the produced nematodes. Moreover, the harvest quality is demonstrated by the length of the produced nematodes. The length of IJ is determined by several factors such as the insect host, the concentration of nematodes, and the total nematodes production. The nematodes productions via $T$. molitor and $S$. litura showed IJ nematodes in the length of approximately $325-986 \mu \mathrm{m}$ (Tables 4 and 5). Both T. molitor and S. litura exhibited their highest production rates on the 6th and 10th day after the treatment with IJ length 647.67 and $986.67 \mu \mathrm{m}$ respectively.

The Asembagus nematode isolates that are produced through $T$. molitor, and $S$. litura is relatively similar in size (325-986 $\mu \mathrm{m})$ compared to other types of nematodes such as $S$. carpocapsae (325-488 $\mu \mathrm{m}), S$. abbasi $(496-579 \mu \mathrm{m}), S$. karii $(876-982 \mu \mathrm{m}), S$. riobravis $(561-701 \mu \mathrm{m})$ and $H$. marelatus $(588-700 \mu \mathrm{m})$. Chaerani et al. (2018), stated that Steinernema and Heterorhabditis in Indonesia have body length of infective juveniles of 360-762 $\mu \mathrm{m}$ and 386-599 $\mu \mathrm{m}$ respectively. IJ which produced in T.molitor and S.litura showed a good result, this is possible because $S$. carpocapsae Asembagus isolates hold an adequate food synthesis level on $T$. molitor and $S$. litura hosts so that its production ability is sufficient to support its development like the four other nematodes. It shows that the length of the $S$. carpocapsae produced in T.molitor and S.litura has met the requirement to be utilized as a biological pest controlling agent.

The nematodes harvest from $T$. molitor, and S. litura shows the best length of IJ on the concentration of 400 IJ/larva of $437.48 \mu \mathrm{m}$ and $591.42 \mu \mathrm{m}$, respectively. The early IJ concentration that was invested shows a reducing trend in IJ length. The investment of $400 \mathrm{IJ} /$ larva could produce the longest IJ. It was then followed by 300 IJ/larva, $200 \mathrm{IJ} /$ larva, and $100 \mathrm{IJ} /$ larva concentrations (Table 6). The more the IJ that is invested on the host, the higher the possibility of IJ to penetrate into the hosts. Hence, it led to a more efficient production of IJ that allows IJ production in better length. According to Hazir et al. (2001), host nutrition shall affect the length of IJ that is produced. Nematodes that can efficiently synthesize nutrition in the insect hosts will produce IJ with a good length.

In addition, the type of insect host will also affect the IJ length. S. litura produces IJ in a better length than $T$. molitor with a respective length of $398.02 \mu \mathrm{m}$ and 417.92 $\mu \mathrm{m}$. As stated by bt Hazir et al. (2001), the nutrition in the host will affect the length of the produced IJ. The length of IJ harvested from $S$. litura is greater than that harvested from $T$. molitor. It is made possible because $S$. litura has 17-27\% larger biomass when compared with $T$. molitor, which only has 3.5-6\% biomass. High biomass allows IJ to consume more nutrition. Hence, it gets enough nutrition to develop. Sufficient nutrition is correlated with the production of IJ in a better length. 
Table 4. Body length of infected juveniles of harvested Steinernema carpocapsae inoculated with different concentrations on T. molitor.

\begin{tabular}{lcccccccccc}
\hline $\begin{array}{c}\text { Concentration of IJ } \\
\text { (JI/larvae) }\end{array}$ & $\mathbf{2}$ & $\mathbf{4}$ & $\mathbf{6}$ & $\mathbf{8}$ & $\mathbf{1 0}$ & $\mathbf{1 2}$ & $\mathbf{1 4}$ & $\mathbf{1 6}$ & $\mathbf{1 8}$ & $\mathbf{2 0}$ \\
\hline 100 & $488,00 \mathrm{a}$ & $653,33 \mathrm{a}$ & $761 \mathrm{c}$ & $640,83 \mathrm{c}$ & $986,67 \mathrm{c}$ & $876,67 \mathrm{c}$ & $349,00 \mathrm{c}$ & $387,33 \mathrm{c}$ & $334,67 \mathrm{c}$ & $336,67 \mathrm{c}$ \\
200 & $475,67 \mathrm{a}$ & $661,33 \mathrm{a}$ & $675,67 \mathrm{ab}$ & $483,33 \mathrm{ab}$ & $803,33 \mathrm{ab}$ & $453,67 \mathrm{ab}$ & $474,67 \mathrm{ab}$ & $370,33 \mathrm{ab}$ & $325,00 \mathrm{ab}$ & $285,33 \mathrm{ab}$ \\
300 & $408,33 \mathrm{a}$ & $553,00 \mathrm{a}$ & $767,67 \mathrm{ab}$ & $362,00 \mathrm{ab}$ & $510,00 \mathrm{ab}$ & $623,33 \mathrm{ab}$ & $546,67 \mathrm{ab}$ & $358,33 \mathrm{ab}$ & $343,33 \mathrm{ab}$ & $186,67 \mathrm{ab}$ \\
400 & $470,00 \mathrm{a}$ & $403,33 \mathrm{a}$ & $556,67 \mathrm{a}$ & $501,33 \mathrm{a}$ & $465,67 \mathrm{a}$ & $479,67 \mathrm{a}$ & $517,33 \mathrm{a}$ & $344,17 \mathrm{a}$ & $327,67 \mathrm{a}$ & $113,33 \mathrm{a}$ \\
\hline
\end{tabular}

Note: values followed by the same letter in the same column are not significantly different according to DMRT with a $95 \%$ confidence level

Table 5. Length IJ of harvested S. carpocapsae nematodes with a concentration of 100, 200, 300, and 400 IJ/larvae on S. litura.

\begin{tabular}{lcccccccccc}
\hline $\begin{array}{c}\text { Concentration of IJ } \\
\text { (JI/larvae) }\end{array}$ & $\mathbf{2}$ & $\mathbf{4}$ & $\mathbf{6}$ & $\mathbf{8}$ & $\mathbf{1 0}$ & $\mathbf{1 2}$ & $\mathbf{1 4}$ & $\mathbf{1 6}$ & $\mathbf{1 8}$ & $\mathbf{2 0}$ \\
\hline 100 & $408,33 \mathrm{a}$ & $514,00 \mathrm{a}$ & $647,67 \mathrm{~b}$ & $362,00 \mathrm{a}$ & $411,67 \mathrm{a}$ & $446,00 \mathrm{a}$ & $390,67 \mathrm{~b}$ & $358,33 \mathrm{~d}$ & $346,67 \mathrm{a}$ & $0 \mathrm{a}$ \\
200 & $417,33 \mathrm{a}$ & $529,67 \mathrm{a}$ & $641,00 \mathrm{ab}$ & $387,33 \mathrm{a}$ & $415,33 \mathrm{a}$ & $434,33 \mathrm{a}$ & $362,33 \mathrm{ab}$ & $369,50 \mathrm{~cd}$ & $343,33 \mathrm{a}$ & $113,33 \mathrm{~b}$ \\
300 & $432,33 \mathrm{a}$ & $416,00 \mathrm{a}$ & $545,67 \mathrm{a}$ & $393,33 \mathrm{a}$ & $456,67 \mathrm{a}$ & $479,33 \mathrm{a}$ & $361,67 \mathrm{ab}$ & $358,50 \mathrm{bc}$ & $333,33 \mathrm{a}$ & $113,33 \mathrm{~b}$ \\
400 & $467,33 \mathrm{a}$ & $403,33 \mathrm{a}$ & $556,67 \mathrm{a}$ & $501,33 \mathrm{a}$ & $472,00 \mathrm{a}$ & $461,33 \mathrm{a}$ & $333,00 \mathrm{a}$ & $344,17 \mathrm{a}$ & $327,67 \mathrm{a}$ & $113,33 \mathrm{~b}$ \\
\hline
\end{tabular}

Note: values followed by the same letter in the same column are not significantly different according to DMRT with a $95 \%$ confidence level

Table 6. Average of Lenght IJ of harvested S. carpocapsae nematodes with a concentration of 100, 200, 300, and 400 IJ/larvae on T. molitor and S. litura

\begin{tabular}{ccc}
\hline $\begin{array}{c}\text { Concentration of IJ } \\
\text { (JI/larvae) }\end{array}$ & \multicolumn{2}{c}{ Length of IJ $(\boldsymbol{\mu m})$} \\
T.molitor & S.litura \\
\hline 100 & $437,68 \mathrm{a}$ & $591,42 \mathrm{~b}$ \\
200 & $431,33 \mathrm{a}$ & $500,83 \mathrm{ab}$ \\
300 & $401,17 \mathrm{a}$ & $465,93 \mathrm{a}$ \\
400 & $398,02 \mathrm{a}$ & $417,92 \mathrm{a}$ \\
\hline
\end{tabular}

Note: values followed by the same letter in the same column are not significantly different according to DMRT with a $95 \%$ confidence level

The production of $S$. carpocapsae with concentrations of 100, 200, 300 and $400 \mathrm{IJ} /$ larvae on T. molitor and $S$. litura showed $3.62 \times 10^{3} ; 6.29 \times 10^{3} ; 1.13 \times 10^{4} ; 1.52 \times 10^{4}$; $1.13 \times 10^{4} ; 1.46 \times 10^{4} ; 1.54 \times 10^{4}$; and $1.94 \times 10^{4}$ IJ/larvae, respectively. The highest production of IJ on T. molitor and $S$. litura was found in $400 \mathrm{IJ} /$ larva concentrations producing $8.51 \times 10^{3}$ and $1.94 \times 10^{4} \mathrm{IJ} /$ larva respectively. The IJ harvest from $T$. molitor and $S$. litura shows the longest body length for IJ at a concentration of $400 \mathrm{IJ} /$ larva of $437.48 \mu \mathrm{m}$ and $591.42 \mu \mathrm{m}$, respectively. The production of $S$. carpocapsae with a concentration of $400 \mathrm{IJ} /$ larvae on T. molitor and S. litura showed the highest total yield and body length of IJ. According to the harvest parameter and IJ length, the use of alternative hosts such as T. molitor and $S$. litura is relevant to boost the production of $S$. carpocapsae Asembagus isolates. Nevertheless, the production of $S$. carpocapsae via $T$. molitor is considered more efficient due to the availability of T.molitor in the market.

\section{REFERENCES}

Adams BJ, Nguyen KB. 2002. Taxonomy And Systematic. In: Gaugler R (ed.). Entomopathogenic Nematology. CABI, Wallingford, UK.

Arthurs S, Heinz KM, Prasifka JR. 2004. An analysis of using entomopathogenic nematodes against above-ground pests. Bull Entomol Res 94 (4): 297-306.

Batalla-Carrera L, Morton A, Shapiro-Ilan D, Strand MR, Garcia-DelPino. 2014. Infectivity of Steinernema carpocapsae and S. feltiae to larvae and adults of the hazelnut weevil, Curculio nucum: Differential Virulence and Entry Routes 46 (3): 281-86.

Boemare N, Tailliez P. 2009. Molecular approaches and techniques for the study of entomopathogenic bacteria. In: Stock SP, Vanderberg J, Boemare N, Glazer I. (eds.). Insect Pathogens: Molecular Approaches and Techniques. CABI, Wallingford, UK.

Bjorson S, Schutte C. 2003. Pathogens of mass-produced natural enemies and pollinators. In: van Lenteren JC (eds). Quality Control and Production of Biological Control Agents Theory and Testing Procedures. CABI, Wallingford, UK.

Chaerani, Prabowo H, Indrayani IGAA. 2018. Isolation and molecular identification of entomopathogenic nematodes (Steinernema and Heterorhabditis) from East Java and Bali. Jurnal AgroBiogen 14 (2): 85-96.

Campbell JF, Lewis EE. 2002. Entomopathogenic nematode host search strategies. In: Lewis EE, Campbell JF, Sukhdeo MVK (eds.). The Behavioural Ecology of Parasites. CABI, Wallingford, UK

Constant RHF, Waterfield N, Daborn P. 2010. Insecticidal toxins from Photorhabdus and Xenorhabdus. In: Gilbert LI, Iatrou K, Gill SS (eds.). Insect Control Biological and Synthetic Agents. Academic Press, UK.

Dillman AR, Guillermin ML, Lee JH, Kim B, Sternberg PW, Hallem EA. 2012. Olfaction shapes host-parasite interactions in parasitic nematodes. Proc Natl Acad Sci USA 109 (35): 2324-2333.

Ehlers RU. 2003. Entomopathogenic nematodes in the European biocontrol market. Commun Agric Appl Biol Sci 68: 3-16.

Ehlers RU. 2007. Entomopathogenic nematodes: from science to commercial use. In: Vincent G, Goettel MS, Lazarovits G (eds). Biological Control a Global Perspective. CABI, Wallingford, UK.

Elawad SA, Mousa AS, Shahdad SA, Alawaash, Alamiri A. 2007. Efficacy of entomopathogenic nematodes against red palm weevil in UAE. Acta Hortic 736: 415-420.

Elawad SA, Gowen SR, Hague NGM. 1999. The life cycle of Steinernema abbasi and S. riobrave in Galleria mellonella. J Nematol 1 (7-8): $762-$ 764. 
Gaugler R, Han R. 2002. Production technology. In: Gaugler R. (eds) Entomopathogenic Nematology. CABI, Wallingford, UK.

Georgis R, Koppenhofer AM, Lacey LA, Be' lair G, Duncan LW, Grewal PS, Samish M, Tan L, Torr P, van Tol RWHM. 2006. Successes and failures in the use of parasitic nematodes for pest control. Biol Control 38: 103-123.

Glazer I, Lewis EE. 2000. Bioassays for entomopathogenic nematodes. In: Navon A, Ascher KRS (eds.). Bioassays of Entomopathogenic microbes and nematodes. CABI, Wallingford, UK.

Grewal P, Georgis R. 1999. Entomopathogenic nematodes. In: Hall FR, Menn JJ (eds.) Methods in Biotechnology, Vol. 5: use and delivery. Humana Press, Inc. Totowa, NJ.

Lacey L, Georgis R. 2012.Entomopathogenic nematodes for control of insect pests above and below ground with comments on commercial production. J Nematol 44 (2): 218-225.

Lazarovits G, Goettel MS, Vincent, C. 2007. Adventures in biocontrol. In: Vincent C, Goettel MS, Lazarovits G (eds) Biological Control a Global Perspective. CABI, Wallingford, UK.

Lewis EE, Clarke DJ. Nematode parasites and entomopathogens. In: Vega FE, Kaya HK (eds.). Insect Pathology. 2nd ed. Elsevier, Nederlands.

Lewis EE, Campbell J, Griffin C, Kaya H, Peters A. 2006. Behavioral ecology of entomopathogenic nematodes. J Biol Control 38: 66-79.

Hazir S, Kaya HK, Stock SP, Keskun N. 2003. Entomopathogenic nematodes (Steinernematidae and Heterorhabditidae) for biological control of soil pests. Turkey J Biol 27: 181-202.

Hazir S, Stock SP, Kaya HK, Koppenhofer AM, Keskin N. 2001. Developmental temperature effects on five geographic isolates of the entomopathogenic nematode Steinernema feltiae (Nematoda: Steinernematidae). J Invertebrata Pathol 77: 243-250.

Hunt DJ. 2007. Overview of taxonomy and systematic. In: Nguyen KB Hunt DJ (eds). Entomopathogenic Nematodes: Systematic, Phylogeny, and Bacterial Symbionts. Brill Publisher, Netherlands.

Horowitz A, Ishaaya I. 2012. Advanced Technologies for Managing Insect Pest: An overview. In: Ishaaya I, Reddy S, Horowitz AR. (eds) Advanced Technologies for Managing Insect Pest. Springer, London.

Kaya HK, Vega FE. 2012. Scope and basic principles of insect pathology. In: Kaya HK, Vega FE (eds). Insect Pathology. Academic Press, London.

Kumar S. 2012. Biopesticides: a need for food and environmental safety. J. Biofertil. Biopestic. 3. DOI: 10.4172/2155-6202.1000e107.

Koppenhöfer AM, Ebssa L, Fuzy EM. 2012. Storage temperature and duration affect Steinernema scarabei dispersal and attraction, virulence, and infectivity to a white grup host. J Invertebrat Pathol 112: 129-137.

Koppenhöfer AM, Kaya HK. 2002. Entomopathogenic nematodes and insect pest management. In: Koul O., Dhaliwal G.S. (eds). Microbial Biopesticides. Taylor and Francis, London, UK.

Koppenhöfer AM, Fuzy EM. 2009. Long-term effects and persistence of Steinernema scarabaei applied for suppression of Anomala orientalis (Coleoptera: Scarabaeidae). Biol Control 48: 63-72

Mahar AN, Munir M, Laghari KB. 2004. Production and pathogenicity of four Steinernematids in diamondback moth Plutella xylostlella L. (Lepidoptera: Yponomeutidae). Asian J Plant Sci 3 (4): 484-488.

McMullen JG, Stock SP. 2014. In vivo and in vitro rearing of entomopathogenic nematodes (Steinernematidae and Heterorhabditidae). J Vis Exp 91: 52096. DOI: 10.3791/52096.
Miles C, Blethen CC, Gaugler R. 2000. Using beneficial nematodes for insect pest control. Washington State University, Pullman, WA.

Nicolopoulou-Stamati P, Maipas S, Kotampasi C, Stamatis P, Hens L. 2016. Chemical Pesticides and Human Health: The Urgent Need for a New Concept in Agriculture. Front Public Health 4: 1-8. DOI: 10.3389/fpubh.2016.00148.

Parween T, Jan S, Mahmooduzzafar S, Fatma T, Siddiqui ZH. 2014. Selective effect of pesticides on plant-A review. Crit Rev Food Sci Nutr 56 (1): 160-179.

Pino FGD, Jove M. 2005. Compatibility of entomopathogenic nematodes with fipronil. J Helminthol. 79: 333-337.

Poinar GO. 1990. Taxonomy and biology of Steinernematidae and Heterorhabditidae. In: Gaugler R, Kaya HK (eds). Entomopathogenic Nematodes in Biological Control. CRC Press. Boca Raton, FL

Poinar GO, Grewal PS. 2012. History of entomopathogenic nematology. J Nematol 44: 153-161.

Prabowo H. 2007. Kuantitas dan kualitas produksi nematoda patogen serangga pada larva Tenebrio molitor L. (Coleoptera: Tenebrionidae) dan Tirathaba rufivena W. (Lepidoptera: Pyralidae). [Hon. Thesis]. Fakultas Biologi, Universitas Gadjah Mada, Yogyakarta. [Indonesian]

Prabowo H, Martono E, Witjaksono. 2016. Activity of liquid smoke of tobacco stem waste as insecticide against Spodoptera litura Fabricius larvae. Indonesian J Plant Protect 20 (1): 22-27

Půža V. 2015. Control of insect pests by entomopathogenic nematodes. In: Lugtenberg B. (ed.): Principles of Plant-Microbe Interactions. Springer, Cham, Switzerland

Shapiro-Ilan DI, Gouge DH, Koppenhöfer AM. 2002. Factors affecting commercial success: case studies in cotton, turf and citrus. In: Gaugler R. (ed.). Entomopathogenic Nematology. CABI, Wallingford, UK.

Shapiro-Ilan D, Rojas MG, Morales-Ramos JA, Lewis EE, Tedders WL. 2008. Effects of host nutrition on virulence and fitness of entomopathogenic nematodes: Lipid- and protein-based supplements in Tenebrio molitor diets. J Nematol 40: 13-19.

Stock SP, Hunt DJ. 2005. Morphology and Systematics of Nematodes Used in Biocontrol. In: Grewal PS, Ehlers RU, Shapiro-Ilan DI (eds). Nematodes as Biocontrol Agents. CABI, Wallingford, UK.

Smart GCJr. 1995. Entomopathogenic Nematodes for the Biological Control of Insects. J Nematol 27 (45): 529-534.

Umamaheswari R, Sivakumar M, Subramanian S. 2006. Survival and infectivity of entomopathogenic nematodes in alginate gel formulations against rice meal moth larva, Corcyra cephalonica Stainton. Nat Prod Rad 5 (2): 95-98.

van ZylC, Malan AP. 2014. The role of entomopathogenic nematodes as biological control agents of insect pests, with emphasis on the history of their mass culturing and in vivo production. African Entomol 22: 235-249.

Wright DJ, Peters A, Schroer S, Fife JP, 2005. Application technology. In: Grewal PS, Ehlers RU, Shapiro-Ilan DI (eds). Nematodes as Biocontrol Agents. CABI, Wallingford, UK.

Zaki FA, Mantoo MA, Gul S. 2000. In vivo culturing of entomopathogenic nematodes, Heterorhabditis bacteriophora and Steinernema carpocapsae on silkworm (Bombyx mori) and their effect on some lepidopterous insects. Indian J Nematol 30 (1): 1-4 